\title{
PODE O PRIMEIRO CINEMA SER UMA EXPERIÊNCIA?
}

Veridiana Chiari Gatto

\section{RESUMO}

O presente ensaio visa discutir a questão: "Pode o primeiro cinema ser uma experiência?". Para tanto, num primeiro momento, faremos uma breve apresentação da temática da experiência nos textos benjaminianos da década de 30; seguiremos conceituando o que entendemos por primeiro cinema contrapondo-o à codificação da linguagem cinematográfica narrativa do período pós-Griffth e; finalmente, aproximaremos o primeiro cinema da experiência do narrador tradicional, da poesia lírica de Baudelaire e do teatro épico de Bertold Brecht, a fim de problematizarmos a possibilidade de ser o primeiro cinema uma experiência, tal qual a entendia Walter Benjamin.

Palavras-chave: Walter Benjamin. Primeiro Cinema. Experiência. Narrativa. Imagem.

\section{CAN THE EARLY CINEMA BE AN EXPERIENCE?}

\begin{abstract}
The essay intends to discuss the question: "Can the early cinema be an experience?" First, will be done a presentation of the the experience theme on Benjaminian 1930s texts; then, the essay will go on concepting what is understood by early cinema, comparing it to the codification of cinematographic narrative language in the postGriffith period; finally, will be approximated theearly cinema to the tradicional narrator's experience, to the Baudelaire's lyrical poetry and to the Bertold Brecht's epic theatre, in order to problematize the possibility to be the early cinema an experience, as understood by Walter Benjamin.
\end{abstract}

Key-Words: Walter Benjamin. Early Cinema. Experience. Narrative. Image.

\section{Notas sobre a experiência.}

Podemos entender a obra de Walter Benjamin como uma obra constelacional: por mais que seus temas pareçam infinitamente distantes uns dos outros, há, por assim dizer, afinidades insuspeitas entre eles e que se relacionam com uma inquietação que perpassou toda a sua produção: como produzir formas de pensamento que não podem ser apropriadas pelo fascismo?

O tema da experiência (Erfahrung) no capitalismo foi um dos problemas com os quais Benjamin se debateu durante toda a sua existência: se, por um lado, ele 
tenta definir o conceito de experiência como pretérito à emergência do capitalismo, encontrando-se esta inevitavelmente em declínio; por outro, ele tenta desesperadamente encontrar outras formas de experiência capazes de sustentar suas urgências contemporâneas.

Sem nos propormos fazer uma ampla discussão sobre os diversos conceitos de experiência presentes em toda a trajetória da obra benjaminiana, nos deteremos aqui, de forma mais amiúde, nos textos da década de 30, a saber: "Experiência e Pobreza"; "O Narrador", "A obra de arte na era de sua reprodutibilidade técnica" e "Sobre alguns temas em Baudelaire".

Nos dois primeiros ensaios, Benjamin faz o diagnóstico que estamos pobres em experiência e, ainda, que esta pobreza relaciona-se intimamente com o declínio da narrativa, forma pela qual as sociedades arcaicas garantiriam uma memória e uma palavra comuns. A experiência não é entendida como algo que se pode adquirir, mas, transmitir; não é patrimônio de um indivíduo, está entre as pessoas. Por este motivo Benjamin não pode pensá-la isoladamente, mas apenas por meio de relações que não seriam mais possíveis no modo de produção capitalista, como, por exemplo, a íntima relação entre a alma, o olho e as mãos.

Em "O Narrador" Benjamin retira a palavra de seu estatuto predominante na narrativa e põe a coordenação entre os olhos e as mãos como matéria-prima da alma que será tecida na narrativa - entretanto, não deixa de ressaltar que a arte de narrar está eminentemente ligada à oralidade, isto é, é também tributária da voz. O corpo, não seria aquele desmembrado pelas relações de trabalho no capitalismo, mas, sendo tecido por relações de trabalho artesanais, é, tal qual o artesanato, produtor e produto da narrativa:

Ela [a narrativa] imprime a coisa na vida do narrador para em seguida retirála dele. Assim se imprime na narrativa a marca do narrador, como a mão do oleiro na argila do vaso ${ }^{1}$.

Um dos acontecimentos que Benjamin vincula à queda da narrativa é o aparecimento do romance - forma esta que, mesmo remetendo-se à antiguidade, só encontra terreno fértil ao seu florescimento com a ascensão da burguesia, no

1 BENJAMIN, Walter. O narrador. Considerações sobre a obra de Nikolai Leskov. In: BENJAMIN, Walter. Magia e técnica, arte e política. São Paulo: Brasiliense, 1994, p. 197-221. - (Obras escolhidas; v. 1) pp. 220-221.

Veridiana Chiari Gatto - Doutoranda pelo Programa de Pós-Graduação em Psicologia da Universidade Federal Fluminense (UFF). Brasileira, residente em Rio de Janeiro - RJ, E-mail: veridianachiarigatto@ gmail.com 
período moderno - e fundamentalmente, à informação, ambos aplacados da cultura oral e solidamente construídos na cultura escrita, via o nascimento da imprensa. $\mathrm{O}$ lugar de onde se narra é essencialmente divergente do lugar do romance. Enquanto o narrador só existe numa relação de alteridade, onde quem narra e quem escuta fazem parte do processo da narrativa, que instaura-se entre ambos. "O romancista segrega-se. A origem do romance é o indivíduo isolado"2.

No caso da informação, segundo Benjamin, o abismo é ainda mais profundo: ela deve ser compreensível "em si e para si", não existem aberturas ou brechas para outros caminhos, está fechada hermeticamente num sentido dado e, ao contrário da narrativa que se abria para o maravilhoso e para o miraculoso, a informação deve ser, impreterivelmente, plausível. A informação precisa explicar os fatos e eles devem ter uma aparência de razoabilidade, ao contrário, "metade da arte narrativa está em evitar explicações"3. A narrativa não diz nada sobre os fatos que conta, ela mostra as imagens dos fatos, ao invés de preencher os vazios, abre espaços para que quem ouve possa preenchê-los. A narrativa seria, em suma, a arte do inacabamento ético.

Enquanto na narrativa, a experiência que está em jogo é a Erfahrung; com a emergência do romance e da informação, temos um outro tipo de experiência, a Erlebnis, a experiência vivida pelo indivíduo isolado, aquela que não pode mais ser transmitida, mas encerra-se na privacidade do corpo de quem a vive.

Talvez um dos pontos mais importantes que podemos reconhecer concomitantemente como causa e como efeito do fim da arte de narrar, tenha sido a supressão da experiência da morte na vida moderna. Para Benjamin, o declínio da arte de narrar está intrinsecamente ligado à repulsa à morte que as sociedades modernas fizeram emergir com seus dispositivos higiênicos e sociais. A morte, na modernidade, tem algo de obsceno que deve ser mantido fora do olhar dos vivos. Mas não seria apenas a morte física do corpo humano que estaria em jogo neste processo. O envelhecimento, a caducidade, a degeneração, tudo aquilo que apareça como perecível deve ser expulso da vida pública e privada dos homens. No entanto, embora a morte enquanto espetáculo estivesse desaparecendo, o mesmo não podemos dizer de sua presença viva no cotidiano citadino, pois, para Benjamin "esse

\footnotetext{
Ibid., p.201.
}

Ibid., p.201

Veridiana Chiari Gatto - Doutoranda pelo Programa de Pós-Graduação em Psicologia da Universidade Federal Fluminense (UFF). Brasileira, residente em Rio de Janeiro - RJ, E-mail: veridianachiarigatto@gmail.com 
processo, que expulsa gradualmente a morte da esfera do discurso vivo (...) ao mesmo tempo dá uma nova beleza ao que está desaparecendo"4.

Em Experiência e Pobreza, Benjamin nos fala que a única maneira de produzirmos uma experiência na modernidade seria nos livrarmos de toda a experiência, confessando a nossa pobreza de experiência e fazendo do contemporâneo uma tábula rasa, isto é, evitarmos a todo custo nos voltarmos ao passado em busca de referências que nos fariam cair, inevitavelmente, em uma nostalgia perniciosa:

não se deve imaginar que os homens aspirem a novas experiências. Não, eles aspiram a libertar-se de toda experiência, aspiram a uma mundo em que possam ostentar tão pura e tão claramente sua pobreza interna e externa, que algo de decente possa resultar disso ${ }^{5}$.

E talvez seja esta pobreza de experiência e esse olhar que dá nova beleza ao que está desaparecendo que faça com que Benjamin se volte à poesia lírica de Baudelaire. É no ensaio Sobre alguns temas em Baudelaire que Benjamin mira a Erlebnis, isto é, a experiência vivida, como o tipo de experiência possível na modernidade. Segundo Silva:

É verdade que o tempo da vivência é distinto da experiência. (...) Porém, Benjamin, ao que parece, está mais inclinado a adotar uma perspectiva crítica em relação ao caráter da Erlebnis, perspectiva que, sem se negar a compreender a extrema pobreza dessa vivência, nem por isso deixa de ver um bom destino para ela na figura de Baudelaire. E se há um bom destino, certamente haverá mais de um. (...) O materialismo histórico de Benjamin sempre corrente - não poderia se acovardar defendendo uma experiência simulada, quando, materialmente, o que haviam era pessoas na cidade com suas vivências. ${ }^{6}$

O materialismo de Benjamin não poderia abrir mão das inquietações do presente e se voltar para um passado idílico - que ele define como mítico - que tem a força das verdades encarceradoras. Talvez, a única forma de haver uma experiência, no sentido da Erfahrung, fosse entrar radicalmente no terreno da Erlebnis, como o fez Baudelaire com sua poesia urbana e também Kafka, com uma

${ }^{4}$ Ibid., p. 209

5 BENJAMIN, Walter. Experiência e Pobreza. In: BENJAMIN, Walter. Magia e técnica, arte e política. São Paulo: Brasiliense, 1994, p. 197-221. - (Obras escolhidas; v. 1) p. 118.

6 SILVA, João Grabriel Lima. O castelo da experiência: Walter Benjamin e a literatura medieval. 23/08/2012. Dissertação (Mestrado) - Universidade Federal Fluminense. Niterói. Agosto de 2012. p. 82.

Veridiana Chiari Gatto - Doutoranda pelo Programa de Pós-Graduação em Psicologia da Universidade Federal Fluminense (UFF). Brasileira, residente em Rio de Janeiro - RJ, E-mail: veridianachiarigatto@gmail.com 
literatura que não tinha "(...) nenhuma mensagem definitiva para transmitir, (...) [onde] não existe uma totalidade de sentidos, mas somente trechos de histórias e de sonhos"7.

De alguma maneira, a poesia lírica de Baudelaire nos põe numa relação de experiência com a modernidade. Ao trazer a caducidade da metrópole moderna isto é, ao trazer a morte e a fragilidade da cidade - e a Erlebnis para o centro de sua poesia lírica, Baudelaire instaura uma transmissibilidade, embora bem diversa daquela do narrador tradicional e salva a experiência, ainda que por meio de sua pobreza. Segundo Gagnebin:

Benjamin não insiste tanto na recusa da grande cidade por Baudelaire, mas muito mais no fato de que a sua poesia urbana é uma poesia da transitoriedade e da fragilidade. É porque os poemas de Baudelaire dizem a cidade na destrutibilidade que, paradoxalmente, eles perduram, ao contrário da poesia triunfalista de Verhaeren, por exemplo... ${ }^{8}$

A morte, para Benjamin, é a maior inimiga do modo de vida burguês. Era dela que derivava toda a autoridade do narrador, mas também é dela que deriva a possibilidade de ver imagens: "Aquilo que sabemos que em breve não teremos diante de nós, torna-se imagem." ${ }^{\circ 9} \mathrm{O}$ poder de ver imagens está intimamente ligado à morte. Se, no caso da narrativa tradicional, derivada da oralidade, a alma, o olho e a mão estavam inscritas no mesmo campo, com a invenção da fotografia:

Pela primeira vez no processo de reprodução da imagem a mão foi liberada das responsabilidade artísticas mais importantes, que agora cabiam unicamente ao olho. Como o olho apreende mais depressa que a mão desenha, o processo da reprodução das imagens experimentou tal aceleração que começou a situar-se no mesmo nível que a palavra oral. ${ }^{10}$

São as imagens, na modernidade, que podem nos abrir à possibilidade da experiência que antes só poderia vir da tradição oral, elas tomam o lugar que havia ficado vazio com o declínio da arte de narrar e nos colocam numa relação

${ }^{7}$ GAGNEBIN, Jeanne Marie. Prefácio - Walter Benjamin ou a história aberta. n: BENJAMIN, Walter. Magia e técnica, arte e política. São Paulo: Brasiliense, 1994, p. 07-20. - (Obras escolhidas; v. 1). p. 18.

8 Idem. Baudelaire, Benjamin e o moderno. In: Sete aulas sobre linguagem, memória e história. Rio de Janeiro: Imago, 1997. p.147.

9 BENJAMIN, Walter. Charles Baudelaire. Um lírico no auge do capitalismo. São Paulo:Brasiliense, 1989. (Obras escolhidas; v. 3). p.84.

${ }^{10}$ Idem. A obra de arte na era de sua reprodutibilidade técnica. In: BENJAMIN, Walter. Magia e técnica, arte e política. São Paulo: Brasiliense, 1994, p. 165-196. - (Obras escolhidas; v. 1). p.167.

Veridiana Chiari Gatto - Doutoranda pelo Programa de Pós-Graduação em Psicologia da Universidade Federal Fluminense (UFF). Brasileira, residente em Rio de Janeiro - RJ, E-mail: veridianachiarigatto@gmail.com 
privilegiada com o contemporâneo, tornando-nos possível a experiência. Se pensarmos a imagem em seu estatuto de experiência, tal qual o era a palavra oral para o narrador, podemos descobrir, nas imagens do passado, uma força incrivelmente poderosa que pode, doravante, tensionar o nosso contemporâneo. Esta é a proposta do presente ensaio.

\section{O primeiro cinema}

Primeiro cinema é modo como atualmente denomina-se os filmes produzidos no período pretérito à codificação da linguagem cinematográfica por Griffth, isto é, a sobrecodificação das imagens pelo enredo, o momento onde os filmes começam a contar estórias que necessariamente devem ter início, meio e fim. Os filmes do primeiro cinema eram apresentados em feiras, exposições itinerantes, carroças de mambembes, teatros de variedades. Continham em média cinco minutos e não tinham nenhuma existência autônoma, geralmente continham um único plano que se apresentava em sequencia com outros planos, entretanto, sem continuidade temática; ou eram montados intercalados com outros espetáculos.

A fronteira entre ficção e realidade era muito tênue, haviam as "atualidades" que eram cenas filmadas ao ar livre: o movimento das ruas, o porto de uma cidade, cenas da vida cotidiana. Haviam as "atualidades reconstituídas" que eram reconstituições de momentos considerados importantes como guerras, incêndios, assassinatos famosos, etc. A mistura entre o artifício e a realidade parecia não incomodar a audiência, segundo COSTA: "a intenção realista no cinema só viria muito depois, acompanhada de certa forma de narratividade"11. Haviam também os filmes de "Perseguição", esses, mesmo contendo elementos de narratividade, não tendiam à linearização, pois cada plano era filmado como se fosse uma atração. Esses filmes estavam intimamente ligados a uma sensibilidade burlesca, onde a moralidade passaria ao largo: cenas como a de um elefante que é eletrocutado, cai e morre; meninas num quarto que promovem uma briga de travesseiros; uma dançarina movendo seu vestido como uma borboleta; um beijo na boca; etc. Outra característica importante é que esses filmes solapavam o efeito diegético que o cinema narrativo clássico pós-Griffth levaria às últimas consequências:

\footnotetext{
${ }^{11}$ COSTA, Flávia Cesarino. O Primeiro cinema: espetáculo, narração e domesticação. Rio de Janeiro: Azougue, 2005, p. 46.

Veridiana Chiari Gatto - Doutoranda pelo Programa de Pós-Graduação em Psicologia da Universidade Federal Fluminense (UFF). Brasileira, residente em Rio de Janeiro - RJ, E-mail: veridianachiarigatto@gmail.com
} 
(...) o primeiro cinema exibe inúmeras descontinuidades. Além disso, o observador era repetidamente chamado a participar da cena, a responder aos acenos e piscadelas dos atores, que se dirigiam ostensivamente à câmera e deixam claro que sabem da nossa presença. Há, enfim, inúmeros momentos em que se rompe a diegese. Costuma-se usar o termo diegese para designar o ambiente autônomo da ficção, o mundo da história que está sendo contada. Diegese é o processo pelo qual o trabalho de narração constrói um enredo que deslancha de forma aparentemente automática, como se fosse real, mas numa dimensão espaço-temporal que não inclui o expectador. $\mathrm{O}$ efeito diegético será mais intenso quanto menos evidentes forem as mercas de enunciação do discurso. A diegese articula-se diretamente com certas formas de narração, seja ela literária, teatral ou cinematográfica. Quanto maior é a impressão de realidade, mais diegético é o efeito da ficção. A diegese pode ser solapada, inversamente, todas as vezes em que aparecem sinais de que se trata de um discurso construído... ${ }^{12}$

Ao contrário do que se imagina, o espectador deste primeiro cinema não era ingênuo, ele não se incomodava com a mistura entre ficção e realidade porque sabia estar fazendo parte de um jogo. A intenção destes espectadores era muito mais encantar-se, maravilhar-se, espantar-se com as imagens que, inicialmente estáticas, iam ganhando movimento. Eles sabiam estar diante de um truque, a maioria dos aparelhos deixaria entrever seu mecanismo, efeito este chamado de visibilidade pelos estudos sobre o "primeiro cinema". Entretanto, ainda que existisse esta explicitação, o efeito de ilusão não deixaria de existir, fenômeno este chamado fantasmagoria.

Era o choque, o paradoxo entre a visibilidade e fantasmagoria que possibilitava a estes espectadores o encantamento, o maravilhamento, o espanto. $O$ primeiro cinema, ao acolher este paradoxo como parte da experiência do espectador, contradiz a ideia muito difundida de que a cultura visual popular baseava-se em representações realistas, enquanto que pequenos grupos de vanguarda tinham a prevalência sobre as expressões modernistas:

Permanece, assim, um modelo confuso de visão no século XIX, que se bifurca em dois níveis: em um deles, um grupo relativamente pequeno de artistas mais avançados criou um tipo de visão e de significação radicalmente novo, enquanto no nível mais cotidiano a visão permaneceu inserida nas mesmas limitações "realistas" gerais que a haviam organizado desde o século XV. Tal divisão conceitual induz à noção errônea de que a corrente chamada realista dominou as práticas de representações populares, enquanto experimentações e inovações ocorriam em uma arena

12 Ibid., p.46.

Veridiana Chiari Gatto - Doutoranda pelo Programa de Pós-Graduação em Psicologia da Universidade Federal Fluminense (UFF). Brasileira, residente em Rio de Janeiro - RJ, E-mail: veridianachiarigatto@gmail.com 
distinta (ainda que permeável) da criação modernista. ${ }^{13}$

Neste cinema, não experimentaríamos o tempo como continuidade, mas como interrupção, a concepção temporal que estava em jogo não seria a sucessão de um agora para um depois, mas de um agora para um agora ${ }^{14}$, seria um demorarse no instante, tal qual a fotografia. Segundo Lúcia Santaella, a invenção da fotografia possibilitou a emergência de uma outra forma de experienciar o tempo: o instantâneo. Ao passo que a fotografia capturaria e eternizaria o instante, ela também apontaria para seu oposto: a morte irrecuperável de cada momento. ${ }^{15}$

Se o primeiro cinema conhecia a intensividade do tempo do agora, o cinema narrativo que começaria a se insinuar em 1908 e que chegaria ao seu ápice com a codificação da linguagem narrativa cinematográfica por Griffth em 1913, seria a tentativa de organização dos múltiplos agoras em sucessões por meio da criação de ilusões de continuidades num tempo homogêneo e vazio preenchido por histórias lineares. Flávia Cesarino Costa chamará este fenômeno de domesticação do cinema. O irrecuperável do instante, ao passo que abre à possibilidade de experimentar o tempo do agora, também pode causar uma sensação de desamparo, de desalento diante do ocorrido. A domesticação seria, segundo a autora, tanto um

processo de homogeneização na representação do espaço e do tempo, como um processo de enquadramento de forças divergentes, de fabricação de personagens sem ambiguidades, de finais felizes necessários ${ }^{16}$

O cinema anterior a este período era uma atividade marginal, tanto na sua produção, que era majoritariamente artesanal, como na sua recepção, sendo suas formas não-narrativas constantemente atacadas por "estimular um nervosismo insalubre". ${ }^{17}$

Com a instauração da linguagem cinematográfica, a afetação e o direcionamento do olhar dos atores à câmera foi substituindo-se por uma crescente dissimulação dos atores, a montagem começou a apagar os traços de sua

${ }^{13}$ CRARY, Jonathan. As técnicas do observador: visão e modernidade no século XIX. Rio de Janeiro: Contraponto, 2012. p.14.

${ }^{14}$ COSTA, Flávia Cesarino. O Primeiro cinema: espetáculo, narração e domesticação. Rio de Janeiro: Azougue, 2005. p. 213.

${ }^{15}$ Ibid., p.31.

${ }^{16}$ Ibid., p.69.

${ }^{17}$ lbid., p.29.

Veridiana Chiari Gatto - Doutoranda pelo Programa de Pós-Graduação em Psicologia da Universidade Federal Fluminense (UFF). Brasileira, residente em Rio de Janeiro - RJ, E-mail: veridianachiarigatto@gmail.com 
existência, tornando-se invisível; os filmes passaram por uma moralização, tanto dos conteúdos como dos espaços em que eram exibidos; os personagens passam por um adensamento de traços psicológicos; as histórias que eram contadas passaram cada vez mais a integrar um esquema causalístico de aventuras, perdições, punições. Surgindo, assim, o cinema narrativo tal qual conhecemos hoje.

\title{
3. Pode o Primeiro Cinema ser uma experiência?
}

Se partimos, agora, da proposição da imagem em seu estatuto de experiência, tal qual o era a palavra oral para o narrador, podemos descobrir, nas imagens do passado do primeiro cinema, uma força incrivelmente poderosa capaz de tensionar o nosso contemporâneo. Um exemplo de como as antigas narrativas podem nos trazer forças insuspeitadas, é trazido por Benjamin na estória contada por Heródoto sobre o rei egípcio Psammenit. Ao término da narrativa, que é sempre seca e nada dada à explicações, Benjamin conclui:

\begin{abstract}
Ela conserva suas forças por muito tempo e é ainda capaz de se desenvolver. (...) essa história do antigo Egito é ainda capaz, depois de milênios, de suscitar espanto e reflexão. Ela se assemelha a essas sementes de trigo que durante milhares de anos ficam fechadas hermeticamente nas câmaras das pirâmides e que conservam até hoje suas forças germinativas. ${ }^{18}$
\end{abstract}

E se assim o era com as narrativas orais propomos aqui que as primeiras imagens cinematográficas encontram-se igualmente em plena potência; que os primeiros filmes, mesmo depois de muitos anos, conservam, ainda, suas forças germinativas e que essas forças, podem, ainda hoje, nos causar espanto e reflexão. Ora, se fizermos um paralelo, que não se pretende causalístico, entre o declínio da arte de narrar e o declínio do primeiro cinema surpreender-nos-emos que ambos declives mantêm algumas correspondências. Tais correspondências, ou semelhanças, habitam a esfera de um saber oculto que volta-se "menos no registro de semelhanças encontradas que na reprodução dos processos que engendram tais semelhanças"19.

Tal como a narrativa tradicional, o primeiro cinema era uma arte artesanal e

\footnotetext{
${ }^{18}$ BENJAMIN, Walter. O narrador. Considerações sobre a obra de Nikolai Leskov. In: BENJAMIN, Walter. Magia e técnica, arte e política. São Paulo: Brasiliense, 1994, p. 197-221. - (Obras escolhidas; v. 1) p. 204.

${ }^{19}$ Idem. A doutrina das semelhanças. In: BENJAMIN, Walter. Magia e técnica, arte e política. São Paulo: Brasiliense, 1994, p. 108-113. - (Obras escolhidas; v. 1). p. 108 
ainda que fosse uma atividade de massas, não era jamais massificado, pois cada exibição era única, isto é, cada exibição dependia da forma como o operador comporia os filmes entre si e com outros espetáculos: um mesmo filme, ainda que já visto por um espectador, composto com outras sequências de filmes, tornar-se-ia igualmente fascinante mesmo não sendo inédito. O motivo do declínio da narrativa tradicional é, para Benjamin, a emergência do romance e, também, da informação. O primeiro cinema, igualmente, entra em declínio quando o romance e a informação passam a sobrecodificar suas formas artesanais: como sabemos, nos primeiros filmes, não existiam gêneros bem definidos, ainda que muitos tentem ver a origem dos documentários nos filmes de atualidades e a origem do cinema ficcional narrativo, nos filmes de perseguição, sabemos que as experiências que estavam em jogo nesta cinematografia não são, de modo algum, reduzíveis a estas formas posteriores de gêneros. Pois se internamente a estes filmes havia uma permutação de vários gêneros, nos dando imensa dificuldade de categorizá-los em um ou outro gênero, na própria exibição esta lógica era totalmente embaralhada, não nos abrindo margem para experimentá-los como homogêneos. A ficção e o documentário, enquanto gêneros cinematográficos, só fazem sentido num registro posterior ao dos primeiros filmes, essas formas cinematográficas podem ser entendidas mais como tributárias da palavra escrita que, efetivamente, das primeiras imagens em movimento.

Outro importante paralelo entre a narrativa tradicional e o primeiro cinema é que as imagens são secas e não úmidas; o primeiro cinema, esta arte impura, é refratário a qualquer explicação, por este motivo pode abrir-se ao absurdo sem o menor constrangimento, como na narrativa:

o extraordinário e o miraculoso são narrados com a maior exatidão, mas o contexto psicológico da ação não é imposto ao leitor. Ele é livre para interpretar a história como quiser $(\ldots)^{20}$.

Precisamos deixar claro que a narrativa que estamos discutindo neste momento não é a mesma com a qual lidamos ao pensar o cinema. A narrativa cinematográfica, como já tivemos a chance de dizer, surge com a estruturação de uma linguagem cinematográfica por Griffth, que está intimamente ligada à tradição

\footnotetext{
${ }^{20}$ Idem. O narrador. Considerações sobre a obra de Nikolai Leskov. In: BENJAMIN, Walter. Magia e técnica, arte e política. São Paulo: Brasiliense, 1994, p. 197-221. - (Obras escolhidas; v. 1 p. 203. 
romanesca. Mantivemos o uso do mesmo termo para falar de coisas tão distintas mesmo correndo o risco de cair em imprecisões conceituais - por respeitarmos os termos utilizados pelos autores, tanto Benjamin, quando fala da narrativa em sua tradição oral e tanto os teóricos do cinema, quando falam da emergência da linguagem cinematográfica clássica.

O que nos interessa aqui é menos fazer paralelos improfícuos ou meramente acadêmicos entre a narrativa oral e o primeiro cinema que pensar ambos como experiências, isto é, pensá-los em seu poder germinativo mesmo depois de muitos anos após o seu declínio.

Este poder que faz com que os primeiros filmes, tal como a poesia de Baudelaire, mantenham, ainda hoje, sua força desacomodadora preservada, reside no fato de que ambos não se esquivaram de fazer um mergulho sem precedentes na experiência do choque na qual estava imersa a multidão nas metrópoles modernas. Neste sentido, o espectador do primeiro cinema situa-se na mesma posição flâneur que caminha nas grandes cidades, isto é, ambos recebem o choque com a mesma volúpia e alegria. Encaram o caráter destrutivo e desagregador da experiência subjetiva de apagamento dos rastros, aquilo que desagrega o eu, sem nenhum desejo restaurador, mas antes, com receptividade e, ainda intensificando-os.

É neste sentido que a lírica de Baudelaire encarna o conceito positivo de barbárie. Baudelaire não tem nostalgia da tradição, teve de se despojar de toda a cultura para fazer sua poesia aos tropeços, esbarrões, solavancos. Ele trouxe para lírica os temas mais vulgares e chulos. Não seriam mais nos motivos transcendentais que o poeta beberia, mas no perigo da impermanência das imagens urbanas.

Para Benjamin, o reconhecimento desta pobreza de experiência, o despojarse de toda tradição, sem nostalgia, e o jogar-se no perigo da vivência, é o que faz o bárbaro

pois o que resulta desta pobreza de experiência? Ela o impele a partir para frente, a começar de novo, a contentar-se com pouco, a construir com pouco, sem olhar nem para a direita, nem para a esquerda ${ }^{21}$.

Esta destruição de todo o patrimônio tradicional, cujo cinema é o mais

${ }^{21}$ Idem. Experiência e Pobreza. In: BENJAMIN, Walter. Magia e técnica, arte e política. São Paulo: Brasiliense, 1994, p. 197-221. - (Obras escolhidas; v. 1). p. 116.

Veridiana Chiari Gatto - Doutoranda pelo Programa de Pós-Graduação em Psicologia da Universidade Federal Fluminense (UFF). Brasileira, residente em Rio de Janeiro - RJ, E-mail: veridianachiarigatto@gmail.com 
poderoso agente e que tem na lírica baudelairiana sua primeira expressão, muda completamente a forma de recepção da obra. A pintura e a escultura nos convidam à contemplação, é preciso parar diante da obra para lhe observar os traços, a textura, é preciso entrar numa atividade concentrada, imobilizar o corpo para que a alma capte as miríades de nuances da obra. O cinema, por sua vez, procede por choques, o corpo mal pode se acostumar à imagem, esta é vertiginosamente interrompida e seguida de outras imagens. É neste sentido que o cinema não seria uma forma eminentemente visual, mas tátil. Tal como flâneur caminha pela cidade distraído para que as imagens o acossem, o público do cinema apropria-se da distração para que o elemento tátil entre em cena. O cinema, esta forma de arte paradoxal, é aí que o ótico e o tátil embaraçam-se:

\begin{abstract}
Não existe nada na recepção tátil que corresponda ao que a contemplação representa na recepção ótica. (...) $\mathrm{E}$ aqui, onde a coletividade procura a distração, não falta de modo algum a dominante tátil, que rege à reestruturação do sistema perceptivo. (...) Nada revela mais claramente as violentas tensões do nosso tempo que o fato de que esta dominante tátil prevalece no próprio campo da ótica. É justamente o que acontece com o cinema, através do efeito de choque de suas sequências de imagens. ${ }^{22}$
\end{abstract}

O cinema, esta arte aparentemente meramente visual, é, para Benjamin, sinestésica, mobiliza todo o aparelho perceptivo em seus décimos de segundo. Entretanto, quando Benjamin escreve o ensaio $A$ obra de arte na era de sua reprodutibilidade técnica o cinema não estava mais em sua fase inicial, artesanal; mas já havia se tornado indústria, e das mais lucrativas. É possível afirmamos que o cinema que se estruturou posteriormente à queda do primeiro cinema, contém virtualmente ao menos duas possibilidades: a primeira é aquela que mobiliza grandes montantes de capital e se guia pelos interesses da indústria, um cinema que se voltou para a criação de técnicas de montagem que tem por finalidade a construção da identificação do público por meio da diegese, um cinema monumental que se afina muito mais com a tradição romanesca e folhetinesca, isto é, que é muito mais derivado das formas de escrita que emergiram com a invenção da imprensa, que, efetivamente, da criação de uma imagética.

E um outro cinema, cuja preocupação não reside tanto em construir um

\footnotetext{
${ }^{22}$ Idem. A obra de arte na era de sua reprodutibilidade técnica. In: BENJAMIN, Walter. Magia e técnica, arte e política. São Paulo: Brasiliense, 1994, p. 165-196. - (Obras escolhidas; v. 1). p. 194. 
enredo homogêneo, como em ferir o espectador, interromper a diegese para causar espanto. Este cinema aproxima-se mais da arte dadaísta que, propriamente, da tradição cinematográfica que se instaurou pós-Griffith. Pois o cerne da questão é a desvalorização dos valores de mercado e mesmo dos valores tradicionais, as obras convertem-se em tiros que atingem o espectador, são golpes, solavancos. As obras apagam qualquer rastro do eu, não adicionam conteúdos a um eu acabado, destroem qualquer possibilidade de associação ou identificação entre obra e história pessoal, ali, há um deserto subjetivista, não há possibilidade de ver os rastros subjetivos de quem a construiu, são obras essencialmente anônimas.

Enquanto os filmes engajados com a lógica do mercado hipertrofiam a componente ótica, estes outros, ao contrário, fazem a própria ótica converter-se em componente tátil. O perigo da escopia ótica está na associação de ideias pelo espectador, pois a contemplação disponibiliza tempo para que o espectador entre na obra, faça um mergulho tanto nela quando em si mesmo. Numa escopia tátil, ao contrário, é a obra que entra no espetador, este não pode permanecer o mesmo, mas é violado por ela.

Neste sentido, o primeiro cinema do qual nos ocupamos, assemelha-se mais ao teatro épico de Bertold Brecht, que, efetivamente, dos filmes narrativos da indústria cinematográfica. Toda investida do teatro épico está em interromper as ações dos atores para causar o choque nos espectadores, neste teatro, "não existem espectadores retardatários ou espectadores não reiterados com a trama" 23 . A continuidade, o fio da trama no qual se baseia a narrativa, só existe para ser quebrado, interrompido. Ao contrário do drama em que o elemento diegético precisa estar sempre presente, no teatro épico o que interessa é romper com a ilusão, mostrar as artimanhas ficcionais, o artifício. Ao interromper os movimentos dos atores o teatro épico faz aparecer, não as ações e palavras dos atores, mas os gestos.

O teatro épico, como o primeiro cinema, usa a interrupção para fazer aparecer o gesto, por isso não tem nada a dizer, quer mostrar. Ao romper com a ilusão ele não deixa que o espectador deslize na trama, mas, por meio do susto, traz a consciência de ser teatro. A consciência, ao que parece, é o que aproxima tanto a poesia lírica de

\footnotetext{
${ }^{23}$ PEIXOTO, Nelson Brissac. A sedução da barbárie. O Marxismo na modernidade. São Paulo: Brasiliense, 1982, p.170.

Veridiana Chiari Gatto - Doutoranda pelo Programa de Pós-Graduação em Psicologia da Universidade Federal Fluminense (UFF). Brasileira, residente em Rio de Janeiro - RJ, E-mail: veridianachiarigatto@gmail.com
} 
Baudelaire, quando o teatro épico de Brecht, do primeiro cinema. Era a consciência do choque que fazia de Baudelaire, não um simples curioso embriagado pela multidão, mas o flâneur, que mira as fantasmagorias da cidade; no teatro épico de Brecht a consciência estava a serviço da destruição da ilusão e, no primeiro cinema, ela era o elemento de visibilidade que fazia com o que os espectadores soubessem estar fazendo parte de um jogo e, não apenas, entregues à fantasmagoria. É a consciência, aliada à ilusão, à embriaguez, que gera o paradoxo que constitui a modernidade. "Esta mistura de loucura e lucidez, de reflexão e delírio, esta tentativa de transformar a dispersão em conhecimento, é constitutiva da modernidade" ${ }^{24}$.

O primeiro cinema, entretanto, não seria uma arte totalmente desprovida de aura, mas, por assim dizer, seria a arte onde podemos observar de forma mais exemplar, o declínio da aura. Como em Baudelaire, a aura aparece em seu último aceno, como fantasmagoria. A perda do olhar, a impossibilidade de olhar nos olhos e ser correspondido, é uma das grandes inquietações da arte moderna e que emerge com o nascimento das grandes metrópoles, onde cada vez mais estamos próximos de pessoas que não fazem parte de nosso círculo social e com as quais não nos sentimos à vontade em trocar olhares.

A perda do olhar é para Benjamin um dos traços marcantes da experiência moderna. Aquela passante ${ }^{25}$ que se destacou era, para o flâneur, dotada de aura: "única aparição de uma realidade longínqua, por mais próxima que esteja" ${ }^{26}$. É criada pela expectativa que aquilo que encaramos nos encare de volta, por sua vez. Esta capacidade que está se extinguindo na grande cidade com a crise da percepção é parte daquilo que Benjamin chamaria "decadência da aura". ${ }^{27}$

A passante anônima de Baudelaire, lança o seu último olhar que é correspondido pelo poeta, mas num movimento brusco, é arrastada pela multidão, para desaparecer para sempre. A troca de olhares nas grandes cidades só poderia acontecer assim, como fantasmagoria. No primeiro cinema, atores rompem com a diegese fílmica olhando diretamente para o espectador, de alguma forma, os atores pedem, pela última vez, reciprocidade ao olhar. Ainda hoje, assistir a estes filmes

\footnotetext{
24 Ibid., p. 172.

${ }^{25}$ Trata-se do poema À une passante de Charles Baudelaire.

${ }^{26}$ PEIXOTO, Op.Cit. p. 147.

27 Ibid., p. 147.
}

Veridiana Chiari Gatto - Doutoranda pelo Programa de Pós-Graduação em Psicologia da Universidade Federal Fluminense (UFF). Brasileira, residente em Rio de Janeiro - RJ, E-mail: veridianachiarigatto@gmail.com 
nos causa estranhamento, pois nos sentimos impelidos a responder, a devolver o olhar.

Mas talvez o que haja de mais potente, tanto no teatro épico quando nas tremeluzentes imagens do primeiro cinema são a força dos seus gestos. $O$ gesto, este incapturável. Talvez seja aí onde podemos nos encontrar com a beleza do que está desaparecendo, beleza esta que é a própria experiência na modernidade, aquilo que torna possível a transmissibilidade de uma experiência tão pobre, como a Erlebnis; aquilo que faz com a poesia de Baudelaire permaneça viva para nós.

O gesto é, neste sentido, comunicação de uma comunicabilidade. Este não tem propriamente nada a dizer, porque aquilo que mostra é o ser-nalinguagem do homem como pura medialidade ${ }^{28}$.

Por este motivo devemos pensar o cinema dos primeiros tempos menos em termos de citações explícitas que em momentos de relampejo, isto é, momentos de reminiscência:

\begin{abstract}
O cronista que narra os acontecimentos, sem distinguir entre os grandes e os pequenos, leva em conta a verdade de que nada do que um dia aconteceu pode ser considerado perdido para a história, somente a humanidade redimida poderá apropriar-se totalmente de seu passado. Isso quer dizer: somente para a humanidade redimida o passado é citável, em cada um de seus momentos. Cada momento vivido é uma citation à l'ordre du jour - e esse dia é justamente o do juízo final. ${ }^{29}$
\end{abstract}

O que faz do primeiro cinema uma experiência é menos o fato de ele poder ser citado dentro de nossa tradição da cultura ocidental que os momentos em que as experiências que estavam ali em jogo relampejam para nós, no contemporâneo, dentro e fora das salas de cinemas. Nesta passagem das teses Sobre o conceito de história, Benjamin nos apresenta um método no qual só podemos verdadeiramente citar ao abrimos mão das aspas, isto é, só podemos citar quando estamos efetivamente numa relação de experiência com o passado e esta citação não é, jamais, explícita ou capturável.

Vejamos, por exemplo, um filme que tematiza o cinema dos primeiros anos: A invenção de Hugo Cabret (2011), de Martin Scorsese. O filme narra a história de

\footnotetext{
${ }^{28}$ AGAMBEN, Giorgio. Notas sobre o gesto. In: Artefilosofia, Ouro preto, n. 4, p. 09-14, jan.2008. p. 13.

${ }^{29}$ BENJAMIN, Walter. Teses sobre o conceito de História. In: BENJAMIN, Walter. Magia e técnica, arte e política. 1994, p. 222-232. - (Obras escolhidas; v. 1). p. 223. 
Hugo, um menino órfão que vive só no relógio da estação ferroviária de Paris, às voltas com um enigma preso em um autômato e que ligará sua vida a do famoso cineasta dos primeiros tempos George Meliés. Hugo é um herói solitário em busca de uma verdade, o filme cita filmes famosos como a Chegada o trem à estação (1995) dos irmãos Lumiére, e, claro, A viagem à lua (1902), de Meliés, dentre tantos outros. Mas é um filme que não nos tira de nossos confortáveis lugares de espectadores: deslizamos diegeticamente juntos com Hugo, sua solidão, seu desamparo, sua busca que, ao final, encontra o termo do apaziguamento no seio de uma família feliz. Saímos da sala de cinema satisfeitos: nada nos aconteceu. Se, por um lado, o filme faz citações explícitas ao primeiro cinema, este não aparece em sua força formal e desestabilizadora, mas apenas como um conteúdo tematizado, já que o filme incorpora muito mais a tradição romanesca que as imagens dos primeiros filmes, sendo, inclusive uma adaptação para o cinema de um romance homônimo, de Brian Selznick.

Mas existiria, então, outra forma possível para citar o cinema dos primeiros tempos, nos filmes de hoje? Nelson Brissac Peixoto, ao comentar o filme Mauvais sang (1986), de Leos Carax ${ }^{30}$, nos dá uma importante pista. O filme, que oscila entre os gêneros ficção científica e policial, é, na verdade, a história de um amor que não pode se consumar. Mas a beleza do filme não está no enredo e, sim, nos gestos. Carax se propõe a uma importante tarefa: como olhar uma mulher bonita sem idealizá-la? Como mostrar uma mulher no cinema sem que ela se torne imediatamente objeto de desejo de olhares voyeristas e sem que ela demonstre consciência do poder de sedução de sua imagem? Para produzir tal estranhamento, Carax teve de descodificar toda a linguagem cinematográfica, fez a atriz, Juliette Binoche, assistir filmes do cinema mudo para que ela pudesse trazer para o filme um impossível no cinema hodierno: olhar para a câmera. A atriz não somente é vista, mas também vê, ela olha nos olhos dos espectadores. Seu olhar se faz presença. Carax nos faz entrar numa experiência com o cinema dos primeiros tempos, ele cita, mas sem usar aspas, rompendo a diegese e tornando possível estranharmos as imagens repetidas e codificadas do cinema. Ele faz o primeiro cinema relampejar para nós por meio dos gestos e não do conteúdo fílmico e nos faz entrar em uma

30 PEIXOTO, Nelson Brissac"O olhar estrangeiro." In: NOVAES. Adauto. O Olhar. São Paulo: Companhia das letras, 1988. pp.364-365.

Veridiana Chiari Gatto - Doutoranda pelo Programa de Pós-Graduação em Psicologia da Universidade Federal Fluminense (UFF). Brasileira, residente em Rio de Janeiro - RJ, E-mail: veridianachiarigatto@ gmail.com 
experiência com o primeiro cinema. Esta ética das imagens fundada na experiência é aqui, uma urgência no contemporâneo, um modo de, como Benjamin, buscarmos formas de pensamento que não podem ser apropriadas pelo fascismo. 


\section{REFERÊNCIAS}

AGAMBEN, Giorgio. Notas sobre o gesto. In: Artefilosofia, Ouro preto, n.4, p.09-14, jan.2008.

BENJAMIN, Walter. A obra de arte na era de sua reprodutibilidade técnica. In: BENJAMIN, Walter. Magia e técnica, arte e política. São Paulo: Brasiliense, 1994, p. 165-196. - (Obras escolhidas; v. 1)

.O narrador. Considerações sobre a obra de Nikolai Leskov. In: BENJAMIN, Walter. Magia e técnica, arte e política. São Paulo: Brasiliense, 1994, p. 197-221. - (Obras escolhidas; v. 1)

.Teses sobre o conceito de História. In: BENJAMIN, Walter. Magia e técnica, arte e política. 1994, p. 222-232. - (Obras escolhidas; v. 1)

Experiência e Pobreza. In: BENJAMIN, Walter. Magia e técnica, arte e política. São Paulo: Brasiliense, 1994, p. 114- 119. - (Obras escolhidas; v. 1)

. A doutrina das semelhanças. n: BENJAMIN, Walter. Magia e técnica, arte e política. São Paulo: Brasiliense, 1994, p. 108-113. - (Obras escolhidas; v. 1)

Charles Baudelaire. Um lírico no auge do capitalismo. São Paulo: Brasiliense, 1989. (Obras escolhidas; v. 3)

COSTA, Flávia Cesarino. O Primeiro cinema: espetáculo, narração e domesticação. Rio de Janeiro: Azougue, 2005.

CRARY, Jonathan. As técnicas do observador: visão e modernidade no século XIX. Rio de Janeiro: Contraponto, 2012.

GAGNEBIN, Jeanne Marie. Prefácio - Walter Benjamin ou a história aberta. n: BENJAMIN, Walter. Magia e técnica, arte e política. São Paulo: Brasiliense, 1994, p. 07-20. - (Obras escolhidas; v. 1)

Baudelaire, Benjamin e o moderno. In: Sete aulas sobre linguagem, memória e história. Rio de Janeiro: Imago, 1997.

PEIXOTO, Nelson Brissac. A sedução da barbárie. O Marxismo na modernidade. São Paulo: Brasiliense, 1982

. "O olhar estrangeiro." In: NOVAES. Adauto. O Olhar. São Paulo: Companhia das letras, 1988: 361-365.

SILVA, João Grabriel Lima. O castelo da experiência: Walter Benjamin e a literatura medieval. 23/08/2012. Dissertação (Mestrado) - Universidade Federal Fluminense. Niterói. Agosto 2012. http://www.slab.uff.br/images/Aqruivos/dissertacoes/2012/d_2012JoaoGabriel.pdf 